\section{American visceral leishmaniasis dissociated from Lutzomyia longipalpis (Diptera, Psychodidae) in the State of Espírito Santo, Brazil}

\author{
Leishmaniose visceral americana dissociada da \\ presença de Lutzomyia longipalpis (Diptera, \\ Psychodidae) no Estado do Espírito Santo, Brasil
}

\author{
${ }^{1}$ Centro de Ciências da \\ Saúde, Universidade Federal \\ do Espírito Santo, Vitória, \\ Brasil. \\ 2 Instituto Oswaldo Cruz, \\ Fundação Oswaldo Cruz, Rio \\ de Janeiro, Brasil. \\ Correspondence \\ I. S. Pinto \\ Unidade de Medicina \\ Tropical, Centro de Ciências \\ da Saúde, Universidade \\ Federal do Espírito Santo. \\ Av. Marechal Campos 1468, \\ Vitória, ES \\ 29043-900, Brasil. \\ pintoisrael@gmail.com
}

\begin{abstract}
The occurrence of American visceral leishmaniasis in the State of Espirito Santo, Brazil has always been associated with the presence of the Lutzomyia longipalpis vector. The geographic distribution of this vector in this state is related to the presence of specific geoclimatic characteristics, such as a dry climate, low elevations $(<450 \mathrm{~m})$, steep slopes and rocky outcrops. The occurrence of human autochthonous cases of American visceral leishmaniasis in municipalities without these geoclimatic characteristics justifies the present study and our main goal was to test the association between the occurrence of American visceral leishmaniasis and the presence of the Lu. longipalpis. Sand flies were captured monthly from July 2006 to August 2007 using Shannon and CDC traps in two municipalities with records of autochthonous American visceral leishmaniasis and one with no record. We captured 13,112 sand flies, but no Lu. longipalpis was found. The absence of Lu. longipalpis and the possible role of another American visceral leishmaniasis vector in these localities were discussed.
\end{abstract}

Psychodidae; Vector Ecology; Leishmaniasis
Israel de Souza Pinto 1 Claudiney Biral dos Santos 1

Gabriel Grimaldi Jr. 2

Adelson Luiz Ferreira 1

Aloísio Falqueto 1

\section{Introduction}

American visceral leishmaniasis is a zoonotic disease caused by the protozoan Leishmania infantum chagasi (Cunha \& Chagas, 1937) (Kinetoplastida, Trypanosomatidae). Its transmission occurs as a result of the biting of female phlebotomine sand flies infected with the protozoan 1 .

Classic epidemiological studies indicate a strong association between $L$. i. chagasi and the sand fly Lutzomyia longipalpis (Lutz \& Neiva, 1912) (Diptera, Psychodidae) which is pointed out as the main vector of the disease. This correlation is based on the following factors: the occurrence of human and canine American visceral leishmaniasis cases associated with the geographic and ecological distribution of this sand fly species; finding of Lu. longipalpis naturally infected with $L$. $i$. chagasi; experimental infection of $L u$. longipalpis with L. i. chagasi; attraction of Lu. longipalpis to L. i. chagasi reservoirs (dogs and foxes, mainly) and experimental transmission of $L$. $i$. chagasi by infected Lu. longipalpis 1,2,3,4,5,6,7,8,9.

Some authors support the participation of other sand fly species in the transmission of American visceral leishmaniasis 10 , based on their coincidental distribution with the disease. There are also those authors that defend the participation of other arthropods in American visceral leishmaniasis transmission, based on findings of natural infection in fleas 11 and ticks 12 . However, none of these authors confirmed the capacity of 
these arthropods to transmit the disease through biting.

In Brazil, the first American visceral leishmaniasis cases were registered by Penna 13 who found Leishmanias in 41 of 47,000 post-mortem viscerotomy exams. This author registered disease cases in the states of Alagoas, Bahia, Ceará, Pará, Pernambuco, Piauí, Rio de Janeiro, Rio Grande do Norte and Sergipe. At present, around 3,000 new cases of American visceral leishmaniasis are registered annually in Brazil, the majority associated with rural areas. However, urbanization processes of both the disease and the $L u$. longipalpis vector in cities such as Belo Horizonte (Minas Gerais) and Campo Grande (Mato Grosso do Sul) 14,15 have been occurring in the last years.

In Espírito Santo state, American visceral leishmaniasis was first registered by Martins et al. 16, in the municipalities of Colatina and Baixo Guandu. At present, it is distributed in $10 \mathrm{mu}$ nicipalities, all located in the Center-North of the state. In all endemic areas, disease transmission was always associated with the presence of $L u$. longipalpis.

Using the geoprocessing tool within the Geographical Information System, Feitoza et al. 17 studied the geographic and climatic variables of endemic areas in Espírito Santo. The authors concluded that potential areas for the occurrence of American visceral leishmaniasis and Lu. longipalpis present characteristics such as sloping relief, elevation up to 450 meters above sea level, dry climate and rocky outcrops. Those characteristics always appear in the areas with registers of autochthonous American visceral leishmaniasis human cases, which also coincide with the presence of $\mathrm{Lu}$. longipalpis. It is important to note that, until recently, the disease used to be registered only in the municipalities localized in the Rio Doce valley, in the Central-North region of Espírito Santo state. American visceral leishmaniasis had never been registered in municipalities localized in the South portion of the state.

In the last five years, however, three autochthonous disease cases were registered in the municipalities of Rio Novo do Sul and Vargem Alta, in the southern region of Espírito Santo state. Using the Polymerase Chain Reaction and isoenzymes techniques, the etiologic agent isolated from two patients was identified as L. $i$. chagasi. The epidemiological investigation showed no evidence of the introduction by immigrants, and also no evidence of the migration of ill people, or their relatives, to known endemic areas. From a geographic and climatic perspective, the area where new cases occurred is different from the pattern found in endemic areas of the Rio Doce valley, in the Central-North region of the state 17. Moreover, the Southern region of Espírito Santo is isolated from the endemic areas of American visceral leishmaniasis in the Rio Doce valley by geographical and climatic barriers that limit vector dispersion. Yet, the municipalities in the northern part of Rio de Janeiro state that border the municipalities in the South of Espírito Santo state did not register the occurrence of American visceral leishmaniasis cases nor the presence of Lu. longipalpis (unpublished data).

Considering that Lu. longipalpis was never found in collections carried out in the Southern portion of Espírito Santo state, the occurrence of American visceral leishmaniasis cases in this region justified the systematic studies of the sand fly fauna for vector identification. In this sense, the objective of this study was to test the association between the occurrence of American visceral leishmaniasis and the presence of $\mathrm{Lu}$. longipalpis in the new localities that have registered the disease.

\section{Material and methods}

The study was performed in the Central-South region of Espírito Santo state in the localities of Belém district (2047'29" S; 4000'09” W) and Santo Antônio district (2050’40” S; 4056’21” W) that belong, respectively, to the municipalities of Vargem Alta and Rio Novo do Sul, where autochthonous human American visceral leishmaniasis cases had occurred. For the sand fly fauna comparison, Joebinha district $\left(20^{\circ} 41^{\prime} 56^{\prime \prime}\right.$ S; $40^{\circ} 47^{\prime} 41^{\prime \prime}$ W) in the municipality of Alfredo Chaves was also included in the study as it had registered autochthonous American tegumentary leishmaniasis cases.

The three locations present similar geo-climatic characteristics, as follows: humid climate influenced by the air currents coming from the Atlantic Ocean; annual pluviometer indices higher than 1,200mm; and sloping relief, with rare rocky outcrops 17 . The region contains small forest patches that are the remains of the Atlantic Rain Forest which was devastated to give room to coffee crops, and latter, in part, to banana crops and extensive cattle rearing.

In the period between August 2006 and July 2007, monthly sand fly collections were performed exploring: the modified environment, represented by the domiciles in which leishmaniasis cases had occurred, including their annexes and domestic animal shelters; and the preserved environment, represented by secondary forests next to the domiciles. 
The captures were performed during the three initial nocturnal hours using active search in Shannon traps with the help of the Castro suction manual capturer in the modified environment and two CDC light traps installed in the preserved environment.

The collected specimens were placed in tubes containing ethanol (70\%) and taken to the laboratory, where they were assembled according to the technique proposed by Barreto \& Coutinho 18 and identified according to the taxonomic criteria proposed by Galati 19,20. The sand flies' generic names were abbreviated as proposed by Marcondes 21.

Using the PAST program (http://folk.uio.no/ ohammer/past/) 22, the following parameters were estimated in each environment: the specific richness $(\mathrm{S})$, the equitability index $(\mathrm{J})$ and the Shannon diversity index $(\mathrm{H})$.

\section{Results}

A total of 13,112 sand fly specimens belonging to 15 species $(\mathrm{H}=0.59)$ were collected (Table 1$)$. No instance of $\mathrm{Lu}$. longipalpis, the main American visceral leishmaniasis vector in the New World, was captured in the three locations under study.

The only species captured in all three localities were Nyssomyia intermedia (Lutz \& Neiva, 1912) and Micropygomyia schreiberi (Martins, Falcão \& Silva, 1975). Other species appeared in Belém district and Joebinha district including: Lutzomyia alencari (Martins, Souza \& Falcão, 1962), Micropygomyia quinquefer (Dyar, 1929), Migonemyia migonei (França, 1920) and Pintomyia fischeri (Pinto, 1926). Yet some species were captured in just one locality: Brumptomyia nitzulescui (Costa Lima, 1932), Evandromyia edwardsi (Mangabeira, 1941), Evandromyia termitophila (Martins, Falcão \& Silva, 1964), Nyssomyia whitmani (Antunes \& Coutinho, 1939), Pintomyia bianchigalatiae (Andrade-Filho, Aguiar, Dias \& Falcão, 1999), Pintomyia monticola (Costa Lima, 1932), Pintomyia serrana (Damasceno \& Arouck, 1949) and Psathyromyia shannoni (Dyar,1929) in Belém district and Sciopemyia sordellii (Shannon \& Del Ponte, 1927) in Joebinha district.

In Belém district (Vargem Alta), Ny. intermedia was the predominant species both in the preserved and in the modified environment. In the modified ambient, it was followed by $\mathrm{Mg}$. migo$n e i$ and $P i$. fischeri. In the preserved environment though, it was followed by Mi. schreiberi and Pi. fischeri. In Santo Antônio district (Rio Novo do Sul), individuals belonging to only two species were captured in both environment types: $M i$. schreiberi and Ny. intermedia. In this location,
Mi. schreiberi was the predominant species in the modified environment and $N y$. intermedia the predominant species in the preserved environment. In Joebinha district (Alfredo Chaves), $\mathrm{Ny}$. intermedia was the predominant species in the two environment types, followed by Pi. fischeri.

The specific richness (S) and the diversity index $(\mathrm{H})$ were higher in Belém district, both in the modified $(\mathrm{S}=13 ; \mathrm{H}=0.51)$ and in the preserved environments ( $\mathrm{S}=7 ; \mathrm{H}=1.23$ ), when compared with the modified $(\mathrm{S}=2 ; \mathrm{H}=0.52)$ and preserved $(\mathrm{S}=2 ; \mathrm{H}=0.50$ ) environments in Santo Antônio district and with the modified $(\mathrm{S}=4 ; \mathrm{H}=0.21$ ) and preserved ( $\mathrm{S}=6 ; \mathrm{H}=1.03$ ) environments in Joebinha district. When the two environment types were compared, the specific richness was higher for the modified environment in Belém district and for the preserved environment in Joebinha district. In Santo Antônio district, the specific richness was the same for both environment types (Table 1). The diversity index was more than twice the value in the preserved environment compared with the modified environment in Belém district and more than four times the value in Joebinha district, while in Santo Antônio district they were similar (Table 1). In Joebinha district and in Belém district the equitability index was higher for the preserved environment when compared with the modified environment, while in Santo Antônio district the index was similar in both environment types (Table 1).

\section{Discussion}

The sand flies fauna found in the two American visceral leishmaniasis foci in the Central-South portion of Espírito Santo state presents a specific composition very different from that found in other transmission areas in Espírito Santo and in Brazil 15,23. However, this fauna is very similar to that found in typical areas of American tegumentary leishmaniasis transmission, in which the species Ny. intermedia, Mg. migonei and Pi. fischeri predominate, like in the locality of Joebinha (Alfredo Chaves) and in other regions in Espírito Santo and in Brazil 24,25,26,27.

The absence of $L u$. longipalpis in two areas in the South portion of Espírito Santo that registered autochthonous American visceral leishmaniasis human cases suggests a dissociation of the disease occurrence from the presence of this insect in the state. Although in agreement with the geo processing model proposed by Feitoza et al. 17 , this absence is unexpected due to the fact that $\mathrm{Lu}$. longipalpis is considered the only vector of the disease in the Southeastern region of Brazil 23 . 
Table 1

Sand flies collected in modified and preserved environments in the municipalities of Vargem Alta, Rio Novo do Sul and Alfredo Chaves, Espírito Santo State, Brazil, between August 2006 and July 2007.

\begin{tabular}{|c|c|c|c|c|c|c|c|c|c|c|c|c|}
\hline \multirow[t]{3}{*}{ Species } & \multicolumn{6}{|c|}{ Vargem Alta (Belém district) } & \multicolumn{6}{|c|}{ Rio Novo do Sul (Santo Antônio district) } \\
\hline & \multicolumn{3}{|c|}{$\begin{array}{c}\text { Modified } \\
\text { environment }\end{array}$} & \multicolumn{3}{|c|}{$\begin{array}{c}\text { Preserved } \\
\text { environment }\end{array}$} & \multicolumn{3}{|c|}{$\begin{array}{c}\text { Modified } \\
\text { environment }\end{array}$} & \multicolumn{3}{|c|}{$\begin{array}{c}\text { Preserved } \\
\text { environment }\end{array}$} \\
\hline & $\sigma^{\pi}$ & 우 & Subtotal & 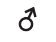 & 우 & Subtotal & 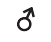 & 우 & Subtotal & $\sigma^{\pi}$ & 우 & Subtotal \\
\hline Brumptomyia nitzulescui & 1 & - & 1 & - & - & - & - & - & - & - & - & - \\
\hline Brumptomyia sp. & - & - & - & - & 2 & 2 & - & - & - & - & - & - \\
\hline Evandromyia edwardsi & 1 & 2 & 3 & 1 & 3 & 4 & - & - & - & - & - & - \\
\hline Evandromyia termitophila & 1 & - & 1 & - & - & - & - & - & - & - & - & - \\
\hline Lutzomyia alencari & - & 1 & 1 & - & - & - & - & - & - & - & - & - \\
\hline Micropygomyia quinquefer & 1 & - & 1 & 1 & 2 & 3 & - & - & - & - & - & - \\
\hline Micropygomyia schreiberi & 8 & 7 & 15 & 8 & 12 & 20 & 33 & 2 & 35 & 1 & - & 1 \\
\hline Migonemyia migonei & 1,032 & 147 & 1,179 & - & 2 & 2 & - & - & - & - & - & - \\
\hline Nyssomyia intermedia & 7,799 & 2,170 & 9,969 & 32 & 21 & 53 & 7 & 2 & 9 & 1 & 3 & 4 \\
\hline Nyssomyia whitmani & 1 & - & 1 & - & - & - & - & - & - & - & - & - \\
\hline Pintomyia bianchigalatiae & - & 3 & 3 & - & - & - & - & - & - & - & - & - \\
\hline Pintomyia fischeri & 346 & 443 & 789 & - & 5 & 5 & - & - & - & - & - & - \\
\hline Pintomyia monticola & - & 1 & 1 & - & - & - & - & - & - & - & - & - \\
\hline Pintomyia serrana & - & 1 & 1 & - & - & - & - & - & - & - & - & - \\
\hline Psathyromyia shannoni & 1 & 1 & 2 & - & - & - & - & - & - & - & - & - \\
\hline Sciopemyia sordellii & - & 1 & 1 & & - & - & - & - & - & - & - & - \\
\hline Total & 9,193 & 2,774 & 11,967 & 42 & 47 & 89 & 40 & 4 & 44 & 2 & 3 & 5 \\
\hline Specific richness (S) & & & 13 & & & 7 & & & 2 & & & 2 \\
\hline Equitability index (J) & & & 0.21 & & & 0.63 & & & 0.73 & & & 0.72 \\
\hline Diversity index $(\mathrm{H})$ & & & 0.57 & & & 1.23 & & & 0.52 & & & 0.50 \\
\hline
\end{tabular}

(continues)

In an area of American visceral leishmaniasis in Pernambuco state in the Brazilian Northeastern region, Carvalho et al. 10 pointed to $\mathrm{Mg}$. migonei as a possible vector of $L$. $i$. chagasi, in spite of not having found females infected with L. $i$. chagasi. For identification of this insect as a vector, the authors took into account mainly their abundance in the intra and peri domiciliary environments of residences in which human cases had occurred. Yet, $M g$. migonei presents an attraction for dogs 28 , which can act as L. i. chagasi reservoirs. In this sense, the finding of this sand fly species in Belém district could explain the occurrence of American visceral leishmaniasis in this locality, but it would exclude Santo Antônio district, where the insect was not captured. Finally, Mg. migonei is found in many municipalities next to the American visceral leishmaniasis endemic areas, even within Espírito Santo state, where the disease was never registered. However, in the Brazilian Southeastern and Northeastern regions, $M g$. migonei has been identified as a secondary vector of Leishmania braziliensis, an etio- logic agent of American tegumentary leishmaniasis, including the finding of females naturally infected with this protozoan 29,30.

The finding of $\mathrm{Lu}$. alencari in the locality of Belém district, although in low density, deserves more detailed studies to verify its possible participation in the American visceral leishmaniasis epidemiology in that locality, especially if one takes into account its phylogenetic proximity with Lu. longipalpis.

In Santo Antônio district, the transmission of the disease might not have occurred due to the sand flies biting since the two species found, $M i$. schreiberi and $\mathrm{Ny}$. intermedia, are not considered disease transmitters among human beings. The first species, Mi. schreiberi, possibly feeds on reptiles and it was never found biting human beings to get fed. The second species, Ny. intermedia, was never found naturally infected with L. i. chagasi, in spite of being anthropophilic, attracted by a domiciliary reservoir such as dogs and able to be experimentally infected. On the other hand, the evidence of the natural infection with L. bra- 
Sand flies collected in modified and preserved environments in the municipalities of Vargem Alta, Rio Novo do Sul and Alfredo Chaves, Espírito Santo State, Brazil, between August 2006 and July 2007.

\begin{tabular}{|c|c|c|c|c|c|c|c|c|c|}
\hline \multirow[t]{3}{*}{ Species } & \multicolumn{6}{|c|}{ Alfredo Chaves (Joebinha district) } & \multicolumn{3}{|c|}{ Total } \\
\hline & \multicolumn{3}{|c|}{$\begin{array}{l}\text { Modified } \\
\text { environment }\end{array}$} & \multicolumn{3}{|c|}{$\begin{array}{c}\text { Preserved } \\
\text { environment }\end{array}$} & \multirow[b]{2}{*}{$\widetilde{\sigma}$} & \multirow[b]{2}{*}{ 우 } & \multirow[b]{2}{*}{ Subtotal } \\
\hline & 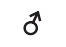 & 우 & Subtotal & $\sigma$ & 우 & Subtotal & & & \\
\hline Brumptomyia nitzulescui & - & - & - & - & - & - & 1 & - & 1 \\
\hline Brumptomyia sp. & - & - & - & - & - & - & - & 2 & 2 \\
\hline Evandromyia edwardsi & - & - & - & - & - & - & 2 & 5 & 7 \\
\hline Evandromyia termitophila & - & - & - & - & - & - & 1 & - & 1 \\
\hline Lutzomyia alencari & - & 1 & 1 & 1 & 1 & 2 & 1 & 3 & 4 \\
\hline Micropygomyia quinquefer & - & - & - & 3 & 3 & 6 & 5 & 5 & 10 \\
\hline Micropygomyia schreiberi & - & - & - & 1 & - & 1 & 51 & 21 & 72 \\
\hline Migonemyia migonei & 1 & - & 1 & - & - & - & 1,033 & 149 & 1,182 \\
\hline Nyssomyia intermedia & 872 & 30 & 902 & 24 & 13 & 37 & 8,735 & 2,239 & 10,974 \\
\hline Nyssomyia whitmani & - & - & - & - & - & - & 1 & - & 1 \\
\hline Pintomyia bianchigalatiae & - & - & - & - & - & - & - & 3 & 3 \\
\hline Pintomyia fischeri & 40 & 9 & 49 & 4 & 3 & 7 & 390 & 460 & 850 \\
\hline Pintomyia monticola & - & - & - & - & - & - & - & 1 & 1 \\
\hline Pintomyia serrana & - & - & - & - & - & - & - & 1 & 1 \\
\hline Psathyromyia shannoni & - & - & - & - & - & - & 1 & 1 & 2 \\
\hline Sciopemyia sordellii & - & - & - & - & - & - & - & 1 & 1 \\
\hline Total & 913 & 40 & 953 & 33 & 21 & 54 & 10,221 & 2,891 & 13,112 \\
\hline Specific richness (S) & & & 4 & & & 6 & & & 15 \\
\hline Equitability index (J) & & & 0.15 & & & 0,71 & & & 0.21 \\
\hline Diversity index $(H)$ & & & 0.21 & & & 1.03 & & & 0.59 \\
\hline
\end{tabular}

ziliensis together with the insect anthropophily, the coincidental distribution with American tegumentary leishmaniasis and the attraction for reservoir animals, leads us to believe that this species could be considered the main disease transmitter in the Southeastern region of Brazil 25,27,28.

It is possible that fleas can participate in the transmission of American visceral leishmaniasis in Santo Antônio district since infection by $L$. $i$. chagasi was detected in females of Ctenocephalides felis felis (Bouché, 1835) by means of kDNAPCR (unpublished data). However, the sensibility of the molecular technique can allow the detection of the parasite DNA in the blood ingested by the fleas of an infected dog and therefore it does not prove that these parasites can install themselves in the flea's digestive tract to be transmitted to other dogs or to human beings.

The fauna found both in Belém district and in Santo Antônio district were similar to those found in Joebinha district. The predominance of Ny. intermedia shows the potential for American tegumentary leishmaniasis transmission in these areas, but does not prove American visceral leish- maniasis transmission in the region. Yet, the finding of $P i$. fischeri in the localities of Belém district and Joebinha district supports the fact that the fauna has a pattern typical of that found in an American tegumentary leishmaniasis transmission area, since the species, like $\mathrm{Mg}$. migonei, is incriminated as a secondary vector of the disease.

The fact that the species richness and diversity index are higher in Belém district may be related to the size of the forest fragment and the composition of the vegetation around the fragment in the preserved environment. In this location, the forest fragments are bigger and located next to banana trees, unlike in the other locations that contain smaller fragments that are next to cattle rearing areas. On the other hand, the higher species richness for the modified environment in Belém district can be related with the proximity of residences to the forest and with the presence of food sources for chicken and pigs. The diversity index and the equitability index, as expected, were higher in the preserved environment in Belém and Joebinha districts. Possibly, the forest 
represents a system in equilibrium, with smaller variations of temperature and humidity, favoring the development of sand flies.

In conclusion, the present study dissociates the occurrence of autochthonous American visceral leishmaniasis human cases from the presence of Lu. longipalpis, as this insect is not found in two foci of the disease in the southern part of Espírito Santo state. Moreover, the study contributes to the sand flies fauna knowledge in the region and points out the possibility of the participation of other sand fly species, apart from Lu. longipalpis, in the transmission of American visceral leishmaniasis in these locations. Considering the absence of sand flies suspected of transmitting the American visceral leishmaniasis in Santo Antônio district and the low frequency of the two species collected in these locales, it is possible that other vectors or other transmission mechanisms occur in the region. However, additional studies that reinforce this hypothesis must be developed, including the investigation of natural infection in sand flies and the investigation of possible $L$. $i$. chagasi vertebrate reservoirs in these localities in both domestic and sylvatic environments.

\section{Resumo}

A ocorrência de leishmaniose visceral americana no Estado do Espírito Santo, Brasil, sempre foi associada à presença do vetor Lutzomyia longipalpis. A distribuição geográfica desse vetor no estado está relacionada à ocorrência de características geoclimáticas específicas, tais como clima seco, baixas altitudes, relevo acidentado e afloramentos rochosos A ocorrência de casos humanos autóctones de leishmaniose visceral americana em municípios sem essas características geoclimáticas justificou o presente estudo, com objetivo de testar a associação entre a ocorrência de leishmaniose visceral americana e a presença de Lu. longipalpis. Flebotomí- neos foram capturados mensalmente de julho de 2006 a agosto de 2007 com uso de armadilhas de Shannon e CDC em dois municípios com registros de leishmaniose visceral americana autóctone e um sem registros. Foram capturados 13.112 flebotomíneos, mas nenhum Lu. longipalpis foi encontrado. A ausência de Lu. longipalpis e a possível participação de outro vetor de leishmaniose visceral americana nessas localidades foram discutidas.

Psychodidae; Ecologia de Vetores; Leishmaniose 


\section{Contributors}

I. S. Pinto participated in the collection of the sand flies, species identification, data analysis and interpretation and the writing up of the article. C. B. Santos and A. L. Ferreira participated in the sand fly collection, species identification and writing up the article. G. Grimaldi Jr. writing up the article and was responsible for the leishmania species identification. A. Falqueto participated in the sand fly collection, writing up the article and was responsible for coordinating the study.

\section{Acknowledgments}

Our thanks to the Núcleo de Entomologia e Malacologia at the Espírito Santo State Ministry for Health and the Tropical Medicine Unit at the Federal University of Espirito Santo for their support in carrying out this project. To the Coordenação e Aperfeiçoamento de Pessoal de Nível Superior (CAPES) for a grant for I. S. Pinto. And to Drs. Yuri L. R. Leite, Marcelo T. Tavares and Reginaldo P. Brazil for their comments on earlier drafts. To L. G. S. R. Bauzer for translated the manuscript.

\section{References}

1. Deane LM. Leishmaniose visceral no Brasil: estudos sobre reservatórios e transmissores realizados no Estado do Ceará. Rio de Janeiro: Serviço Nacional de Educação Sanitária; 1956

2. Chagas E, Cunha AM, Ferreira LC, Deane L, Deane G, Guimarães FN, et al. Leishmaniose visceral americana. Relatório dos trabalhos realizados pela Comissão encarregada do estudo da leishmaniose visceral americana em 1937. Mem Inst Oswaldo Cruz 1938; 33:89-229.

3. Deane LM, Deane MP. Isolation of leishmaniae in the viscera and the skin of a fox in the kala-azar endemic zone in Sobral, Ceará. O Hospital 1954; 45:419-21.

4. Deane MP, Deane LM. Infecção experimental do Phlebotomus longipalpis em raposa (Lycalopex vetulus) naturalmente parasitada pela Leishmania donovani. O Hospital 1954; 46:171-3.

5. Deane LM, Deane MP. Observações preliminares da importância comparativa do homem, do cão e da raposa (Lycalopex vetulus) como reservatórios de Leishmania donovani, em área endêmica do calazar, no Ceará. O Hospital 1955; 48:79-98.
6. Deane LM, Deane MP Visceral leishmaniasis in Brazil: geographical distribution and transmission. Rev Inst Med Trop São Paulo 1962; 4:198-212.

7. Grimaldi G, Tesh RB, McMahon-Pratt D. A review of the geographic distribution and epidemiology of leishmaniasis in the New World. Am J Trop Med Hyg 1989; 44:687-725.

8. Grimaldi G, Tesh RB. Leishmaniases of the New World: current concepts and implications for future research. Clin Microbiol Rev 1993; 6:230-50.

9. Lainson R, Dye C, Shaw JJ, MacDonald DW, Courtenay O, Souza AA, et al. Amazonian visceral leishmaniasis - distribution of the vector Lutzomyia longipalpis (Lutz \& Neiva) in relation to the fox Cerdocyon thous (Linn.) and the efficiency of this reservoir host as a source of infection. Mem Inst Oswaldo Cruz 1990; 85:135-7.

10. Carvalho MR, Lima BS, Marinho-Júnior JF, Silva FJ, Valença HF, Almeida FA, et al. Phlebotomine sandfly species from an American visceral leishmaniasis area in the Northern Rainforest region of Pernambuco State, Brazil. Cad Saúde Pública 2007; 23:1227-32. 
11. Coutinho MTZ, Linardi PM. Can fleas from dogs infected with canine visceral leishmaniasis transfer the infection to other mammals? Vet Parasitol 2007; 147:320-5.

12. Coutinho MTZ, Bueno LL, Sterzik A, Fujiwara RT, Botelho JR, De Maria M, et al. Participation of Rhipicephalus sanguineus (Acari: Ixodidae) in the epidemiology of canine visceral leishmaniasis. Vet Parasitol 2005; 128:149-55.

13. Penna HA. Leishmaniose visceral no Brasil. Bras Med 1934; 48:948-9.

14. Silva SS, Gontijo CMF, Pacheco RS, Fiuza VOP, Brazil RP. Visceral leishmaniasis in the metropolitan region of Belo Horizonte, state of Minas Gerais, Brazil. Mem Inst Oswaldo Cruz 2001; 96:285-91.

15. Oliveira AG, Galati EAB, Oliveira O, Oliveira GR, Espindola IAC, Dorval MEC, et al. Abundance of Lutzomyia longipalpis (Diptera: Psychodidae: Phlebotominae) and urban transmission of visceral leishmaniasis in Campo Grande, state of Mato Grosso do Sul, Brazil. Mem Inst Oswaldo Cruz 2006; 101:869-74.

16. Martins J, Souza JC, Silva E. Primeiros casos autóctones de leishmaniose visceral no Espírito Santo. O Hospital 1968; 73:69-97.

17. Feitoza LR, Stocking M, Rezende M. Natural resources information systems for rural development: approaches for Espírito Santo State, Brazil. Vitória: Editora Incaper; 2001.

18. Barreto MP, Coutinho JO. Processos de captura, dissecação e montagem de flebótomos. Ann Fac Med São Paulo 1940; 16:173-87.

19. Galati EAB. Phylogenetic systematics of Phlebotominae (Diptera, Psychodidae) with emphasis on American groups. Bol Dir Malariol San Amb 1995; 35:133-42.

20. Galati EAB. Morfologia e taxonomia. In: Rangel EF, Lainson R, organizadores. Flebotomíneos do Brasil. Rio de Janeiro: Editora Fiocruz; 2003. p. 23-175.

21. Marcondes CB. A proposal of generic and subgeneric abbreviations for Phlebotominae sandflies (Diptera: Psychodidae: Phlebotominae) of the world. Entomol News 2007; 118:351-6.

22. Hammer Ø, Harper DAT, Ryan PD. PAST: Palaeontological statistics software package for education and data analysis. Palaeontol Electronica 2001; 4:1-9.
23. Barata RA, Silva JCF, Costa RT, Fortes-Dias CL, Silva JC, Paula EV, et al. Phlebotomine sand flies in Porteirinha, an area of American visceral leishmaniasis transmission in the state of Minas Gerais, Brazil. Mem Inst Oswaldo Cruz 2004; 99:481-7.

24. Barros GC, Sessa PA, Mattos EA, Carias VRD, Mayrink W, Alencar JTA, et al. Foco de leishmaniose tegumentar americana nos municípios de Viana e Cariacica, estado do Espírito Santo, Brasil. Rev Saúde Pública 1985; 19:146-53.

25. Ferreira AL, Sessa PA, Varejão JBM, Falqueto A. Distribution of sand flies (Diptera: Psychodidae) at different altitudes in an endemic region of American cutaneous leishmaniasis in the state of Espírito Santo, Brazil. Mem Inst Oswaldo Cruz 2001; 96:1061-7.

26. Hermeto MV, Dias DV, Genaro O, Rotondo-Silva A, Costa CA, Toledo VPCP, et al. Outbreak of cutaneous leishmaniasis in the Rio Doce valley, Minas Gerais, Brazil. Mem Inst Oswaldo Cruz 1994; 89:519-21.

27. Rangel EF, Meneses CRV, Cupolillo E, Azevedo ACR, Costa WA, Costa SM. Aspectos da ecologia de Lutzomyia intermedia (Lutz \& Neiva, 1912) e a fauna flebotomínica (Diptera: Psychodidae) em área de transmissão da Leishmania (V.) braziliensis no Rio de Janeiro. Rev Soc Bras Med Trop 1999; 32:115.

28. Falqueto A. Especificidade alimentar de flebotomíneos em duas áreas endêmicas de leishmaniose tegumentar no Estado do Espírito Santo [Tese de Doutorado]. Rio de Janeiro: Instituto Oswaldo Cruz, Fundação Oswaldo Cruz; 1995.

29. Azevedo ACR, Rangel EF, Queiroz RG. Lutzomyia migonei (França, 1920) naturally infected with peripylarian flagellates in Baturité, a focus of cutaneous leishmaniasis in Ceará State, Brazil. Mem Inst Oswaldo Cruz 1990; 85:479.

30. Pita-Pereira D, Alves CR, Souza MB, Brazil RP, Bertho AL, Barbosa AF, et al. Identification of naturally infected Lutzomyia intermedia e Lutzomyia migonei with Leishmania (Viannia) braziliensis in Rio de Janeiro (Brazil) revealed by a PCR multiplex non-isotopic hybridisation assay. Trans R Soc Trop Med Hyg 2005; 99:905-13.

Submitted on 25/May/2009

Final version resubmitted on 13/Oct/2009 Approved on 03/Nov/2009 